\title{
PEMIKIRAN KEBAHAGIAAN MENURUT ARISTOTLE DAN IBNU MISKAWAYH: SATU ANALISIS AWALAN
}

(Happiness Thought According to Aristotle and Ibn Miskawah: A Preliminary Analysis)

\author{
MOHD ANNAS SHAFIQ AYOB*, MOHD NORAZRI MOHAMAD ZAINI, FARIDAH \\ MOHD SAIRI \& NOOR SYAHIDA MD SOH
}

\begin{abstract}
ABSTRAK
Kebahagiaan merupakan salah satu topik utama yang mendominasi wacana falsafah etika. Konsep kebahagiaan mula dibincangkan sejak munculnya perbincangan falsafah iaitu pada zaman Yunani klasik seperti yang dibincangkan oleh Aristotle dalam buku Nicomachean Ethic, sehingga dibincangkan dalam tamadun Islam oleh beberapa ahli falsafah Islam seperti Ibn Miskawayh dalam Tahdhib al Akhlaq. Kedua tokoh tersebut mempunyai pendekatan yang berbeza berkaitan konsep kebahagiaan. Justeru, kajian ini menganalisis makna dan cara mencapai kebahagiaan yang telah dibincangkan menurut perspektif dua orang tokoh pemikir tersebut berdasarkan hasil penulisan mereka. Penelitian ini mengetengahkan metode perbandingan makna dan cara mencapai kebahagiaan. Hasil kajian mendapati wujud persamaan dan perbezaan dalam konsep kebahagiaan di antara Aristotle dan Ibn Miskawayh dalam beberapa aspek tertentu. Eudaimonia, merupakan konsep yang dibincangkan melalui perbincangan menerusi pencarian Aristotle melalui persoalan yang menjadi tumpuan manusia iaitu apakah yang menjadi tujuan akhir dan kebaikan yang tertinggi dalam kehidupan manusia. Selain itu, kebahagiaan dapat dicapai melalui aspek pemilihan dan pengawalan tingkah laku serta perbuatan dalam kesederhanaan serta hubungan nalaran yang telah dibincangkan oleh Aristotle dan Ibnu Miskawayh melalui kaitan dan perbezaannya.
\end{abstract}

Kata kunci: Aristotle; Ibnu Miskawayh; Kebahagiaan; Nalaran; Falsafah akhlak

\section{ABSTRACT}

Happiness is one of the main topics that dominated the discourse of ethical philosophy. The concept of happiness began to be discussed since the emergence of philosophical discussions in the era of classical Greece as discussed by Aristotle in the book Nicomachean Ethics until the age of Islamic civilization by several Islamic philosophers such as Ibn Miskawayh in Tahdhib al Akhlaq. The two figures had different approaches regarding the concept of happiness. Hence, this study analyzed the meaning of happiness and how to achieve it according to the perspectives of the two thinkers based on their writings. This study highlighted the method of comparing the meaning of happiness and how to achieve it. The results of the study found that there were similarities and differences in the concept of happiness between Aristotle and Ibn Miskawayh in certain aspects. Eudaimonia is a concept that was discussed in Aristotle's search and discourse; through questions that often became the focus of human beings which are what is the end goal and what is the highest deed in a human's life. Besides, happiness can be achieved through the aspects of selection and control of behaviour as well as actions in moderation. The rational relationship of happiness was also discussed by Aristotle and Ibn Miskawayh through its similarities and differences.

Keywords: Aristotle; Ibnu Miskawayh; Happiness; Reason; Philosophy of ethics 


\section{PENDAHULUAN}

Kebahagiaan merupakan topik utama yang dibincangkan dalam semua agama dan sistem etika. Bagaimanapun, perbincangan kebahagiaan tidak sama bagi kesemua sistem pemikiran, sama ada di dalam sistem etika falsafah Yunani klasik dan Islam. Dalam tradisi masyarakat dan ahli falsafah Yunani klasik, perbincangan kebahagiaan sangat penting kerana menjadi inti bagi setiap perbincangan etika dalam kalangan mereka. Perbincangan tersebut bertitik-tolak dari persoalan apakah tujuan akhir dalam kehidupan manusia. Menurut Holowchak (2004), kebahagiaan yang dibincangkan oleh setiap ahli falsafah Yunani seperti sebuah teka-teki yang perlu dicantumkan kerana kepelbagaian pandangan berkenaan kebahagiaan. Sebagai contoh, Plato mengaitkan tujuan akhir kebahagiaan dengan keadilan, Aristotle menganggap kebahagiaan berkait rapat dengan tingkah-laku yang baik, manakala golongan Epicureanisme dan Cynikisme menganggap keseronokan punca kebahagiaan (Annas 2019). Namun perbincangan kebahagiaan oleh Aristotle boleh dikatakan sebagai kemuncak dan pelengkap bagi perbincangan kebahagiaan Yunani klasik. Ini kerana Aristotle merupakan seorang ahli falsafah Yunani klasik yang membincangkan mengenai kebahagiaan secara lengkap dan sistematik dalam tulisannya Nicomachean Ethics.

Kebahagiaan turut menjadi topik perbincangan secara tradisinya di dalam perbincangan falsafah akhlak Islam. Kebanyakan perbincangan ahli falsafah Islam khususnya dalam bidang akhlak sepenuhnya berbentuk teologikal, iaitu menghubungkan perbincangan kebahagiaan dengan agama iaitu Islam (Ansari 1964). Persoalan yang selalu dikaitkan dengan matlamat tertinggi kehidupan manusia seperti kesihatan, kekayaan, wang, dan ilmu sering disalah erti sebagai kebahagiaan. Namun sebenarnya kesemua kriteria tersebut bukanlah pengakhiran dalam hidup melainkan untuk mencapai sesuatu perkara yang lain disebut sebagai kebahagiaan dan menjadi matlamat tertinggi pendidikan akhlak (Nasir 2003). Dalam hal ini, Ibn Miskawayh merupakan ahli falsafah akhlak Islam yang terawal membincangkan kebahagiaan secara sistematik dalam tulisannya iaitu Tahdhib al-Akhlaq bagi menjawab persoalan-persoalan tersebut. Dalam makalah ini, pengkaji merungkai dan menganalisis konsep kebahagiaan menerusi dua orang tokoh yang mewakili dua sudut berbeza iaitu Aristotle, seorang ahli falsafah Yunani klasik, dan Ibnu Miskawayh, seorang ahli falsafah akhlak Islam.

\section{LATAR BELAKANG PENYELIDIKAN}

Kajian kebahagiaan yang lepas terutamanya dalam aspek kebahagiaan Aristotle dari perspektif falsafah akhlak Islam masih belum meluas. Kebanyakan kajian kebahagiaan Aristotle lebih memfokuskan perbincangan dari aspek secara sekular dalam ciri psikologi dan sifat manusia seperti yang disebut Muhammad Abul Quasem (1975). Walau bagaimanapun wujud kajian secara terperinci dari sudut selain kebahagiaan seperti kajian-kajian sebelum ini. Sebagai contoh Majid Fakhry (1975) dalam tulisannya Justice in Islamic Philosphical Ethics: Miskawayh's Mediating Contribution dan Y Mohamed (2000) yang bertajuk Greek Thought in Arab Ethics: Miskawayh's Theory of Justice hanya membandingkan pandangan falsafah etika Ibn Miskawah dan Aristotle dalam konsep keadilan. Banyak kajian analisis yang menyentuh dan membincangkan mengenai konsep kebahagiaan Aristotle dan Ibn Miskawayh dihasilkan secara berasingan. Melalui kajian Alparslan Açikgenç (2008), konsep etika Aristotle dibincangkan menerusi kacamata Islam secara umum. Mohsen Joshanloo (2013) turut membincangkan aspek kebahagiaan Barat menerusi perspektif hedonisme dan kebahagiaan Aristotle secara ringkas. Beliau membawa dua konsep tersebut kerana keduanya melatari sistem etika dalam masyarakat Barat kini dan lebih memfokuskan aspek persamaan dan perbezaan diantara Barat dan Islam dari sudut psikologi dan kesihatan mental. Manakala kajian 
kebahagiaan secara berasingan seperti Mohd Nasir Omar di dalam beberapa artikelnya seperti Islamic Social Ethics: An Analysis of Miskawayh's Thought (2016) membincangkan bagaimana mencapai kebahagiaan menurut Ibn Miskawayh. Selain itu, Mohd Nasir Omar (2018) dalam The Soul (al-Nafs) and Its Effects On Character: An Analysis of the Thought of the Great Muslim Moralist, Miskawayh (D.1030) turut membincangkan mengenai peranan jiwa manusia dalam membentuk kebahagiaan menurut Ibn Miskawayh. Justeru, kajian ini adalah perlu bagi memahami eudaimonia secara bukan Barat khususnya menurut perspektif falsafah akhlak Islam. Kajian ini menganalisis secara awalan makna dan cara mencapai kebahagiaan dengan analisis dari sudut persamaan dan perbezaan diantara persepktif Aristotle dan Ibnu Miskawayh tanpa mengenepikan aspek spiritual yang wujud.

\section{METODOLOGI}

Kajian tekstual, melalui analisis makna dan metode kebahagiaan, digunapakai dengan pengumpulan data bersumberkan karya Aristotle dan Ibn Miskawayh. Oleh itu pengumpulan maklumat yang berbentuk data yang berkaitan subjek kajian seperti bahan yang berkaitan falsafah akhlak terutamanya karya Aristotle yang membincangkan mengenai konsep kebahagiaan dan ilmuwan Islam lainnya sebagai bandingan hanya lebih tertumpu bersifat mengkaji sahaja. Melalui kaedah ini, sumber rujukan dikumpulkan bertumpu kepada Nicomachean Ethics karya Aristotle dan Tahdhib al-Akhlaq karya Ibn Miskawayh untuk mendapatkan maklumat secara keseluruhan mengenai falsafah akhlak secara umumnya dan perbincangan konsep kebahagiaan secara khususnya melalui Aristotle dan Ibnu Miskawayh. Rujukan melalui tulisan kedua tokoh tersebut bertujuan mengenalpasti perbezaan dan persamaan berkenaan konsep kebahagiaan yang dibincangkan. Kaedah interpretasi digunakan beserta analisis data yang dibuat secara induktif dan deduktif. Proses induktif ini merupakan proses di mana penyelidik membentuk hipotesis daripada hasil dapatan yang dikumpulkan dan bukan yang ditentukan dari awal penyelidikan (Othman 2012). Proses interpretasi adalah melalui pemahaman dan perbandingan pandangan kebahagiaan kedua tokoh tersebut. Seterusnya, hasil interpretasi dirumuskan melalui proses induktif dan deduktif bagi memperjelas konsep kebahagiaan yang dibincangkan oleh kedua tokoh tersebut. Hasil intipati melihat aspek elemen persamaan dan perbezaan pemikiran kebahagiaan menurut Aristotle dan Ibn Miskawayh. Beberapa elemen dikenalpasti dalam perbincangan kebahagiaan seperti makna kebahagiaan, hubungan kebaikan dengan kebahagiaan, kesederhanaan dan fungsi nalaran atau akal.

\section{HASIL DAN PERBINCANGAN}

\section{Eudaimonia Dan Aristotle}

Aristotle, diakui seorang tokoh falsafah Yunani klasik yang mula-mula menyusun perbincangan kebahagiaan secara mendalam dan teratur. Konsep kebahagiaan telah dibincangkan oleh Aristotle yang dikenali oleh masyarakat Yunani klasik pada masa tersebut sebagai Eudaimonia. Eudaimonisme adalah sebuah pandangan dan merupakan nilai yang mendasar dalam prinsip etika Yunani klasik iaitu dengan menjustifikasi perlakuan etika bagi masyarakat Yunani klasik. Istilah eudaimonia telah digunakan sebelum zaman Aristotle lagi. Kesemua ahli falsafah etika Yunani klasik seperti Thales diperingkat awal, Democritus, golongan Sofis, Socrates serta Plato dikenali sebagai eudaimonistic iaitu orang yang membincangkan mengenai konsep kebahagiaan (Prior 2001). 


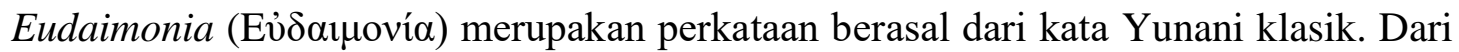
segi etimologinya. Eudaimonia terdiri dari perkata $\mathrm{eu}$ yang bermaksud baik atau kesejahteraan, dan daimon yang bererti roh atau dewa kecil, digunakan bagi menggambarkan suatu keuntungan yang melimpah-ruah. Oleh kerana itu, menjadi orang yang eudaimon merupakan seseorang yang hidup dengan baik, terpelihara dan dijaga oleh roh yang baik. Meskipun penggunaan popular istilah kebahagiaan merujuk pada keadaan fikiran dan perasaan yang berkaitan dengan kegembiraan atau kesenangan, akan tetapi eudaimonia tidak juga ditafsirkan sebagai kebahagiaan dan sering ditafsirkan dengan perasaan lain (Anagnostopoulos 2009). Walau terdapat perbezaan dari segi penafsiran pada masa kini, secara umumnya eudaimonia dirujuk sebagai kebahagiaan (Kraut 1979). John Cooper (1986) menggunapakai perkataan 'kehidupan yang menyenangkan' bagi menggambarkan eudaimonia merujuk kefahaman Aristotle.

Bagi masyarakat Yunani klasik, etika ialah mengenai cara untuk mencapai eudaimonia (O'Grady 2005). Malah, eudaimonia merupakan konsep yang utama dan dibincangkan dalam teori etika Yunani klasik (Annas 1998). Walaupun bagi masyarakat Yunani, etika adalah berkenaan eudaimonia, tetapi persoalan bagaimanakah seseorang dapat mencapai kebahagiaan secara mendalam timbul dan menjadi perbincangan dalam kalangan ahli falsafah dan juga masyarakat umum. Sesetengah pendapat menyatakan pencapaian dalam politik dan kekayaan dianggap sebagai mencapai kebahagiaan. Aristotle menyatakan kekayaan dan politik juga salah satu ciri yang boleh membawa kepada eudaimonia namun Aristotle menafikan kekayaan dan politik sebagai tujuan utama kehidupan manusia (O'Grady 2005). Dalam hal ini, walaupun umum bersetuju kebahagiaan sebagai tujuan utama, namun terdapat juga tujuan utama yang lain seperti kekayaan, kesihatan, keseronokan dan sebagainya. Justeru, disebabkan banyaknya tujuan, Aristotle menjustifikasikan tujuan utama dalam kehidupan yang sepatutnya menjadi pilihan paling akhir manusia.

\section{Eudaimonia Sebagai Tujuan Utama}

Aristotle menegaskan setiap perbuatan menuju kearah sebuah tujuan dan persoalan timbul apabila banyaknya tujuan akhir yang dicapai oleh manusia. Setiap tindakan mempunyai matlamat dan tujuan akhir dan hanya kebahagiaan tujuan utama dan akhir bagi manusia. Aristotle menjelaskan jika terdapat hanya satu tujuan terakhir atau utama (ends), maka tujuan tersebutlah yang ingin dicapai. Jika terdapat banyak tujuan, maka yang paling akhir dan tertinggi dipilih sebagai tujuan paling akhir (Aristotle 1962). Aristotle menyatakan terdapat tiga asas pembahagian yang terdapat dalam tujuan utama. Pertama, terdapat tujuan utama yang kita pilih dengan makna mencapai tujuan lain seperti kesihatan. Kedua, terdapat tujuan yang kita ingini semata-mata untuk mencapai tujuan tersebut seperti setia kawan, keseronokan dan kemegahan. Kemudian yang terakhir merupakan tujuan yang akhir bagi semua tujuan iaitu eudaimonia (Lim 1996). Aristotle menyebutkan kesemua tujuan tersebut bukanlah bersifat pengakhiran, jika wujud tujuan yang bersifat pengakhiran, maka itulah yang sepatutnya dicari oleh manusia yang tidak lain dan tidak bukan adalah kebahagiaan (Aristotle 1962).

Aristotle menjelaskan jika sebenarnya terdapat sesuatu tujuan bagi setiap perbuatan manusia, yang sepatutnya dipentingkan adalah nilainya (for its own sake) dan bukan untuk mencapai sesuatu tujuan yang lain dan setiap perbuatan yang kita lakukan adalah untuk tujuan itu, maka kita tidak akan memilih setiap perbuatan untuk sesuatu tujuan yang lain, kerana jika setiap perbuatan yang dipilih itu adalah untuk mencapai sesuatu tujuan lain, maka proses ini akan berterusan, dan ini bermaksud keinginan seseorang kearah kebahagiaan tidak akan tercapai. Justeru, terdapat suatu kebaikan yang disebut sebagai kebaikan (tujuan) utama yang dipentingkan nilainya semestinya adalah kebahagiaan (Aristotle 1962). Sebagai contoh, kekayaan, keseronokan, kesihatan dan kemegahan dicapai demi tujuan akhir yang lain. 
Manakala kebahagiaan merupakan tujuan utama dan suatu tujuan terakhir dalam siri perbuatan manusia yang dicapai melewati tujuan-tujuan akhir yang lainnya.

Istilah tujuan utama dan kebaikan tertinggi berkait antara satu sama lain. Eudaimonia merupakan kebaikan tertinggi bagi manusia. Namun apakah yang dimaksudkan dengan kebaikan tertinggi (highest good)? Bagi menerangkan kriteria kebaikan tertinggi, pertama, beliau menyatakan mengenai kebaikan tertinggi tersebut mestilah bersifat pencapaian yang terakhir dan tidak wujud lagi kebaikan lain Ini kerana banyak kriteria kebaikan lain yang boleh disimpulkan sebagai kebaikan tertinggi seperti kekayaan, keseronokan dan sebagainya. Namun kriteria kebaikan tertinggi menurut Aristotle bukanlah seperti kekayaan seperti yang telah dinyatakan sebelum ini kerana kekayaan menurut beliau kekayaan bukanlah satu-satunya keinginan yang terus iaitu tidak bersifat pengakhiran dan kekayaan itu berbentuk materialistik (Smith 2001). Kekayaan hanyalah alat untuk mencari kebaikan lain iaitu kebaikan yang bermaksud kebaikan tertinggi.

Kedua, kebaikan tertinggi ini mestilah sesuatu kebaikan yang jelas dan hanya terdapat pada manusia. Salah satu kebaikan seperti keseronokan tidak boleh dijustifikasikan sebagai kebaikan tertinggi kerana haiwan juga merasai keseronokan. Kebaikan tertinggi tertumpu kearah manusia dan ini hanya boleh dicapai oleh manusia dan bukan makhluk yang lain. Aristotle mengatakan, baik untuk kita menjadi seorang yang kaya, namun sesetengah manusia hancur disebabkan oleh kekayaan. Keseronokan juga tidak boleh dijelaskan sebagai suatu kebaikan kepada manusia apabila dibawa bersama perbincangan mengenai kebahagiaan. Justeru perkataan yang sesuai bagi merujuk kebaikan tertinggi adalah kebahagiaan (Aristotle 1962). Kebahagiaan bukanlah suatu keadaan mental, perasaan kepuasan hati atau suatu sikap tertentu, tetapi merupakan suatu aktiviti, dan aktiviti tersebut dilakukan dan dialami sepanjang kehidupan.

\section{Eudaimonia Dan Fungsi Nalaran}

Seseorang mencapai tujuan terakhir dengan menjalankan fungsinya dengan baik. Sebagai contoh, tujuan terakhir bagi seorang pemain muzik adalah dapat bermain muzik dengan baik dan tukang kasut dapat membuat kasut dengan baik. Justeru jika manusia menjalankan fungsinya sebagai manusia dengan baik, maka manusia tersebut dapat mencapai tujuan terakhirnya iaitu kebahagiaan. Fungsi khas tersebut merupakan akal iaitu keunggulan yang ada pada manusia berbanding makhluk lain, dalam erti kata lain manusia mencapai kebahagiaan, disamping menjalankan fungsinya dengan baik, ia turut melibatkan aktiviti rasionalnya iaitu nalar atau akal dengan secara paling baik (Bertans 2003). Akal juga berperanan penting untuk mencapai eudaimonia. Manusia mempunyai fungsi khusus dan tidak dikongsi oleh makhluk lain. Fungsi tersebut sudah tentu bukan untuk memenuhi kelazatan fizikal dan indera, kerana fungsi tersebut lebih terkhusus kepada haiwan (Nasir 2010).

Dari sudut lain, untuk mencapai eudaimonia, seseorang mestilah dapat memenuhi fungsinya secara sempurna, iaitu merujuk kepada keupayaan akal untuk berfikir dan berhujah (O'Grady 2005). Setiap orang dewasa mempunyai keupayaan tersebut namun tidak semua yang dapat menyempurnakannya. Beliau menyebut manusia dicipta untuk berfikir dan dengan menggunakan akal dengan menyempurnakan keupayaan tersebut, manusia dapat mencapai kebahagiaan. Inilah yang membezakan manusia dengan makhluk lain seperti haiwan dan tumbuhan. Aristotle meletakkan keupayaan manusia untuk mencapai kebahagiaan disebabkan kelebihan adanya akal. Aristotle cuba menghubungkan peranan manusia yang menggunakan akalnya dan yang bertindak sebagai manusia untuk mencapai kebahagiaan yang tidak boleh dimiliki oleh makhluk lain (Idris and Ahmad 2013).

Menurut Aristotle, proses akal penting untuk mencapai kebahagiaan. Akal digerakkan oleh dua kebaikan iaitu kebaikan intelektual dan kebaikan moral. Kebaikan intelektual 
menyempurnakan akal, manakala untuk kebaikan moral, akal menjalankan pilihan yang perlu dalam kehidupan seharian. Akal yang rasional dilihat menentukan jalan tengah di antara dua ekstrem yang bertentangan (Aristotle 1962). Dua ekstrim bertentangan ini bermaksud dua keadaan yang bersifat tidak baik, suatu keadaan yang bersifat kurang dan terlalu banyak atau berlebihan (Açikgenç 2008). Kebaikan intelektual lebih unggul dan tinggi lantaran dengannya manusia dapat melaksanakan fungsi utama sebagai manusia, di samping itu mereka dapat memanfaatkan anasir yang dibekalkan iaitu akal yang berbentuk anasir ketuhanan. Konsep ini dikenali sebahagi konsep kesederhanaan dalam perbincangan falsafah etika Yunani klasik.

\section{Eudaimonia Dan Kesederhanaan}

Konsep kesederhanaan telah lama dibincangkan oleh ahli falsafah Yunani klasik sebelum Aristotle lagi seperti ditemui dalam perbincangan Plato dan ianya merupakan idea utama dalam pemikiran Yunani klasik (Godfrey 1953). Perbincangan ini melibatkan perbincangan etika dimana ahli falsafah sebelum Aristotle seperti Pythagoras (570-490 SM), telah membincangkan masalah konsep roh dan konsep pertengahan (mean) (Stumpf 1994). Menurut Max Horten (1974), apa yang dimaksudkan dengan konsep kesederhanaan Aristotle ialah kesederhanaan memimpin manusia melalui jalan yang lurus daripada terjebak dengan bahayabahaya yang ada di sekelilingnya. Maka kebaikan sejati akan diketemukan jika manusia mengikuti konsep kesederhanaan.

Konsep keseimbangan mewakili di antara sifat kurang dengan terlalu banyak. Sebagai contoh, keberanian merupakan salah satu contoh jalan tengah di antara ketakutan, yang mewakili sifat kekurangan, manakala tekad dan gopoh-gapah, mewakili sifat berlebihan. Kemurahan hati merupakan adalah keutamaan yang mencari jalan tengah antara ketamakan dan pemborosan. Konsep kesederhanaan dicapai melalui akal yang dapat mengenal pasti di antara kebaikan dan keburukan dengan mengambil jalan tengah di antara dua sifat iaitu kurang dan terlalu banyak disampaikan oleh Aristotle dengan menamakannya sebagai konsep kesederhanaan (golden mean) (Cunningham 1999). Beliau menerapkan konsep kesederhanaan yang mana menunjukkan keprihatinan beliau dalam mencapai etika yang seimbang untuk mencapai kebahagiaan. Banyak contoh sifat yang diberikan oleh Aristotle yang berkait dengan kesederhanaan seperti sabar, di mana sabar merupakan sifat di antara marah dan kelesuan, dan sifat ramah di antara sifat bengis dan pendiam (Godfrey 1953).

Maka untuk mencapai kebahagiaan, manusia mesti bertingkah laku secara sederhana. Mereka mesti berani, pemurah, sabar, jujur, adil dan sebagainya. Kerana keberanian merupakan titik tengah yang berada di antara takut dan gopoh-gapah; manakala pemurah pula berada di pertengahan antara sifat kedekut dan boros dan begitulah dengan sifat-sifat kesederhanaan lain seperti adil, jujur, amanah dan sebagainya. Keutamaan yang menentukan kesederhanaan disebut oleh Aristotle sebagai phronesis (kebijaksanaan praktikal). Phronesis dianggap sebagai penentu terhadap apa jua bentuk kesederhanaan tertentu (Bertans 2003). Justeru, manusia adalah baik dalam erti moral jika selalu mengadakan pilihan rasional yang tepat dalam kehidupan sehari-hari, memilih sifat kesederhanaan maka orang tersebut layak dikatakan sebagai orang yang bahagia.

\section{Rumusan Konsep Kebahagiaan Menurut Aristotle}

Pada akhirnya, Aristotle telah membuat kesimpulan bahawa kebahagiaan sahajalah merupakan matlamat akhir manusia seperti mana beliau nyatakan “...happiness, since, as we assert, it is the end or goal of human" (Aristotle 1962). Malah, kebahagiaan (eudaimonia) bukanlah satu nama sebuah perasaan atau emosi, yang mana begitulah menurut anggapan ramai (Kraut 1979). Seterusnya, pada awal kesimpulan beliau menegaskan kebahagiaan bukanlah satu bentuk 
karakteristik, iaitu dengan menyatakan semua manusia dalam keadaan tertentu atau situasi tertentu sudah dianggap mencapai kebahagiaan atau tidak dapat mencapai kebahagiaan. Sebagai contoh, seseorang yang tertidur sepanjang hayatnya tidak boleh dianggap 61indaka, dan seseorang yang ditimpa malang sepanjang hidupnya tidak semestinya tidak berhak untuk merasa 61indaka (Aristotle 1962).

Dalam kesimpulannya juga, Aristotle lebih banyak menekankan kebahagiaan dengan aspek politik. Ini kerana mengambil kira keadaan yang melatari masyarakat Yunani Klasik 61indak itu mengutamakan aspek politik sebagai tanggungjawab seorang warganegara terhadap negaranya. Kemampuan seorang individu melaksanakan tanggungjawab terhadap negara (politik) dianggap sebagai kebaikan yang dikagumi oleh masyarakat pada masa tersebut (Nasir 2010). Secara tidak langsung situasi tersebut mempengaruhi kesimpulan kebahagiaan Aristotle. Tiga ciri yang boleh diterima dalam kerangka kehidupan yang 6lindakan, iaitu aktiviti yang dapat membawa kepada kebahagiaan dengan merasai keseronokan, aktiviti berpolitik dan sentiasa merenung atau berfikir (aktiviti berfalsafah) (Urmson 1973). Berpolitik bermaksud keterlibatan masyarakat dalam hal-hal bernegara dan menguruskan masyarakat menyebabkan seseorang menjadi lebih berdisiplin dan baik. Maka aktiviti tersebut dapat membawa seseorang ke dalam 61indakan. Undang-undang negara dapat menjadikan seseorang itu baik malah undang-undang negara kedangkala setengahnya lebih berkuasa dalam membentuk anak-anak berbanding arahan seorang bapa seperti yang dinyatakan oleh Aristotle (Aristotle 1962).

Tuntasnya, kebahagiaan yang dapat disimpulkan menurut Aristotle ialah apabila manusia dapat menjalankan fungsinya dengan baik, dengan cara seseorang itu telah mencapai sesuatu tujuan dan menjustifikasikan konsep pertengahan dalam kehidupan, menggunakan sepenuhnya keupayaan akal secara maksimum serta menunjukkan kecemerlangan dalam tingkah lakunya, dengan menggabungkan keseluruhan aspek tersebut, maka seseorang itu sudah mencapai kebahagiaan. Dengan memahami bahawa bukan kekayaan, keseronokan, kesihatan hanya sebagai pendorong atau 61 indak untuk memperoleh kebahagiaan.

\section{KEBAHAGIAAN MENURUT IBN MISKAWAYH}

Ahmad bin Muhammad Miskawayh (932-1030 M) merupakan seorang tokoh terkemuka dalam membincangkan falsafah akhlak Islam pada zaman klasik. Menurut Ibnu Miskawayh, kebahagiaan merupakan cetusan dari hati dan jiwa yang bersih dan seseorang tidak akan dapat mencapai kebahagiaan yang sempurna tanpa mempelajari hikmah dan falsafah iaitu ilmu pengetahuan. Kebahagiaan semua makhluk terkandung dalam keadaan lengkap dan sempurna melalui perbuatan yang istimewa dan tersendiri. Manakala kebahagiaan manusia adalah hasil manifestasi kebahagiaan yang terkandung melalui perbuatan kemanusiaannya yang benar dengan penuh rasa kecerdasan dan ketajaman akal. Kebahagiaan kadangkala disangka wujud pada makhluk yang tidak rasional seperti haiwan. Namun jika hanya kebahagiaanlah yang dikatakan dapat dikecapi oleh haiwan, 61indaka tidak lebih dari sekadar kemampuan haiwan tersebut untuk melakukan sesuatu perkara (Ibnu Miskawayh 1977). Ini dapat dilihat menerusi pemerhatian terhadap tingkah laku haiwan seperti makan, minum dan rehat, justeru pencapaian tersebut tidak sinonim dengan kebahagiaan dan tidak boleh dianggap sebagai kebahagiaan.

\section{Hubungan Kebahagiaan Dengan Kebaikan}

Ibnu Miskawayh berpendapat bahawa kebahagiaan adalah kebaikan (al-khayr) dan setiap manusia mempunyai sudut pandang yang berbeza mengenai kebahagiaan (Ibnu Miskawayh 1977). Seperti konsep kebaikan yang lain yang merupakan tujuan hidup manusia yang perlu 
dibincangkan dan merupakan perkara asas dan masalah utama dalam kehidupan manusia (Ansari 1963). Perkara lain yang sangat berfaedah dan bermanfaat seperti kesihatan, kekayaan, pembelajaran, dan bersikap baik juga merupakan perkara baik. Beliau mendefinisikan kebahagiaan (al-sa'adah) sebagai kebaikan terakhir dan tertinggi dan kebaikan yang penamat, iaitu terakhir dimaksudkan dalam konteks kebaikan yang tidak memerlukan kepada sesuatu yang lain, selain itu untuk mencapai matlamat ini memerlukan 62indak dalaman serta 62indak luaran (Ibnu Miskawayh 1977).

Sesetengah perkara baik dan kebahagiaan mempunyai kaitannya dengan jiwa (nafs), bersifat fizikal dan kebaikan luaran. Sebagai contoh pengetahuan, sains, hikmah dan keseluruhan subjek falsafah adalah kebaikan yang bersifat spiritual, manakala kecantikan, kesihatan, dan sesetengah karakter atau watak baik yang mempengaruhi jiwa adalah bersifat fizikal, dan 62indak pengaruh luaran seperti sahabat, anak, kemegahan dan sebagainya. (Nasir Omar 2003). Contoh-contoh yang sedemikian itu boleh dilihat sebagai hujah bagi membuktikan kebahagiaan adalah yang terbaik sebagai kebaikan yang penamat, iaitu terakhir, dimana tidak ada lagi rasa atau kebaikan lain yang diperlukan selepas kebahagiaan. Berbeza dengan contoh kebaikan yang telah disebutkan, bahkan setiap contoh kebaikan tersebut sebenarnya dicapai demi memenuhi kehendak yang lain, kehendak lain itu semestinya adalah kebahagiaan.

Persoalan yang dibangkitkan mengenai kebahagiaan, apakah yang terkandung dalam kebahagiaan dan hubungannya dengan kebaikan lain? Seperti yang telah dibincangkan, keseronokan, kemegahan, kekayaan dan kesihatan mungkin dianggap pilihan akhir hidup manusia, namun Ibnu Miskawayh menafikan perkara-perkara tersebut. Keseronokan tidak boleh dihubungkan dengan kebahagiaan kerana keseronokan yang dicapai bukanlah tujuan sesuatu perlakuan. Banyak perkara yang dilakukan bukanlah hanya untuk keseronokan (Ansari 1963). Malah, keseronokan juga bersifat badani atau hanya dapat dirasai oleh bentuk fizikal dan tidak boleh dikaitkan dengan perkara yang bersifat rohani atau kejiwaan. Justeru, jika kebahagiaan berhubung dengan keseronokan 62indaka bermakna merendahkan taraf kebahagiaan, kerana meletakkan tempat rohani (spiritual) kepada jasmani (material), keadaan yang berkekalan kepada keadaan yang sementara, keadaan nyata kepada tidak nyata, dan kedudukan yang tinggi kepada kedudukan yang rendah. Bagi Ibnu Miskawayh, tiada tempat bagi keseronokan dalam kebahagiaan (Ibnu Miskawayh 1977).

Keseronokan lebih berbentuk sifat kehaiwanan berbanding sifat kemanusiaan. Keseronokan juga menggambarkan keadaan 62indakan dengan hanya membuang rasa kesusahan dan kesakitan hanya dengan sementara. Seseorang tidak akan merasa seronok 62indak makan dan minum kecuali setelah merasai kelaparan, setelah kenyang maka timbul rasa keseronokan, namun rasa tersebut akan hilang apabila 62indaka lapar (Ibnu Miskawayh 1977). Oleh itu, keseronokan tidak akan dirasai secara berpanjangan dan selama-lamanya kerana akhirnya keseronokan dikhuatiri bertukar menjadi salah satu elemen 62indakan (Ansari 1963). Kehormatan tidak dapat dihubungkan dengan kebahagiaan kerana ia tidak memberi kesan yang mendalam. Manakala kekayaan dan kesihatan hanyalah dicapai demi mencapai sesuatu disebalik kekayaan dan kesihatan itu sendiri iaitu kekayaan untuk mendapatkan harta material seperti wang, rumah dan sebagainya, kesihatan untuk mendapatkan tubuh fizikal yang kuat (Majid Fakhry 1994).

\section{Fungsi Nalaran}

Menurut beliau, kebahagiaan manusia terkandung di dalam kesempurnaan akalnya dan akal mempunyai dua jenis iaitu teoritikal dan praktikal. Kebahagiaan, pada pandangan Miskawayh hanya mampu dicapai apabila manusia mencapai kesempurnaan pada kedua-dua jenis akal ini (Ibnu Miskawayh 1977). Ibn Miskwayh menekankan aspek teori dan praktikal untuk mencapai 
kebahagiaan. Selain itu, persoalan mengapa kebahagiaan yang dicanangkan oleh Ibnu Miskawayh sebagai kebaikan tertinggi atau kebaikan yang sebaik-baiknya, dan mengapa bukan kebaikan lain seperti keseronokan, kesihatan, dan kekayaan, adalah bermula dengan Ibnu Miskawayh meletakkan manusia sebagai makhluk yang paling mulia, diciptakan dengan tujuan yang sama, untuk mencapai pengakhiran masing-masing yang mana sesuai bagi mereka (Ibnu Miskawayh 1977). Semua tujuan baik tersebut lebih bersifat kebinatangan dan tidak sesuai bagi menganggapnya sebagai tujuan utama manusia. Kebahagiaan tidak mengandungi keseronokan, kekayaan, kesihatan atau kemegahan, namun apakah yang terkandung di dalam kebahagiaan? Persoalan ini terjawab apabila kita menyelidiki fungsi khusus yang ada pada manusia. Ibnu Miskawayh menyatakan, seperti yang telah disebutkan sebelum ini, dimana semua kewujudan di dalam semesta ini tidak kira haiwan, tumbuhan, apa saja bentuk atau elemen seperti api, air, udara dan tanah punyai fungsi khusus masing-masing (Ibnu Miskawayh 1977). Walau bagaimanapun, manusia merupakan kewujudan yang terbaik dalam mempraktikkan fungsi khusus tersendiri demi mencapai kebahagiaan.

Setiap kewujudan mempunyai fungsi khusus yang baik, dan setiap perbuatan akhir bagi semua kewujudan haruslah bersandarkan kepada perkara yang terbaik. Sebagai contoh, kuda yang terbaik adalah kuda yang dapat memberikan khidmatnya yang terbaik kepada penunggangnya sesuai dengan keperkasaan dan kekuatannya. Jika kuda tersebut gagal berfungsi dengan baik, maka hilanglah 63indakan kuda tersebut, dan kuda tersebut sama sahaja fungsinya dengan keldai atau unta yang membawa muatan atau barangan (Nasir Omar 2003). Begitu juga manusia, mereka yang terbaik adalah mereka yang 63indaka melakukan perbuatan yang mencerminkan manusia sebagai kewujudan yang mempunyai akal rasional tidak seperti kewujudan lain. Jika manusia tidak menuruti akal rasional, dengan melahirkan tingkah laku yang tidak baik, maka perbuatan atau tingkah laku tersebut sebenarnya lebih menghampiri ciri kehaiwanan. Maka kebahagiaan tidak akan dapat dicapai, justeru kebahagiaan merupakan kebaikan akhir dari keinginan manusia yang sebenar dan bukan kebaikan lain. Untuk memahami dan menjelaskan apa yang diperkatakan oleh beliau, kita mestilah 63indaka melihat analogi yang beliau tampilkan, sebagai contoh, kesempurnaan sebuah penukul, dapat mengetuk benda yang keras, tetapi kesempurnaan yang tertinggi adalah tugas penukul yang dapat menghasilkan sebentuk cincin. Bagi seorang manusia, kesempurnaan seseorang terletak pada perbuatannya yang berpandukan akal, namun yang lebih sempurna adalah aktiviti yang berkait dengan berfikir, menaakul dan sebagainya.

\section{Kaedah Mencapai Kebahagiaan Ibn Miskawayh}

Seseorang tidak akan mencapai kebahagiaan yang sempurna selagi mana seseorang itu tidak mempelajari dan memperoleh sebahagian daripada hikmah atau ilmu pengetahuan dan menguasai dengan sepenuhnya. Tuntasnya, pengetahuan atau hikmah merupakan jalan untuk mencapai kebahagiaan yang sempurna. Ibnu Miskawayh mengkritik mereka yang menganggap terdapat jalan lain selain menuntut pengetahuan untuk mencapai kebahagiaan. Bagi beliau, mereka yang merasakan sudah mendapat kebahagiaan bukan dengan mempelajari dan menguasai pengetahuan, mereka sebenarnya secara tidak sedar, telah beranggapan dengan anggapan palsu dan menyimpang jauh dari kebenaran (Ibnu Miskawayh 1977).

Ibnu Miskawayh meletakkan kepentingan jiwa dan hati yang bersih sebagai syarat dan cara memperoleh kebahagiaan. Beliau menyebut seseorang yang mencapai kebahagiaan dengan meninggalkan kepentingan dunia, iaitu perkara yang bersifat badani, dan hanya mengambil berat tentang jiwanya iaitu membersihkan jiwa dan menyucikan hati dari keindahan duniawi, maka dia telah 63indaka dan menyediakan dirinya secara spiritual untuk bertemu dengan penciptanya. Kebahagiaan yang dicapai dengan 63indakan lebih bersifat kebahagiaan sejati, bersifat spiritual sesuai dengan keadaan jiwa yang tenang sebagaimana firman Allah 
s.w.t yang menyeru kepada jiwa yang tenang untuk 64indaka kepadaNya (Ibnu Miskawayh 1977). Hasilnya, mereka akan merasa bebas serta rasa keinginan tidak dihalakan untuk perkara duniawi dan menerima cahaya spiritual atau mendapat rahmat dari Allah s.w.t. Kebahagiaan bukan hanya dicapai di dunia, malah mencapai kebahagiaan di akhirat adalah matlamat tertinggi bagi seorang muslim.

Bagi Ibnu Miskawayh lagi, kebahagiaan yang dirasakan jiwa tidak akan lengkap dan mencukupi kecuali dengan menggabungkan kebahagiaan luaran kerana kebahagiaan adalah berbentuk fizikal dan spiritual. Menurut Ibnu Miskawayh, sebagai contoh, pengetahuan merupakan permulaan dan 64indakan atau tingkah laku merupakan akhir natijah dari permulaan tersebut. Sesuatu permulaan tanpa sebuah pengakhiran merupakan perkara yang siasia, manakala sebuah pengakhiran tanpa permulaan adalah mustahil.

\section{PERBANDINGAN}

Ibnu Miskawayh banyak terpengaruh dan terkesan dengan perbincangan kebahagiaan oleh ahli falsafah Yunani klasik khususnya Aristotle. Ibnu Miskawayh mengakui bahawa Aristotle merupakan orang yang awal membincangkan konsep kebahagiaan secara teratur (Nasir Omar 2003). Dalam penulisan Ibnu Miskawayh, khususnya Tahdhib al-Akhlaq, beliau banyak merujuk kepada pandangan Aristotle, walau bagaimanapun beliau kritis terhadap pandangan Aristotle dengan mengemukakan konsep kebahagiaannya tersendiri. Wujud beberapa sisi persamaan dan perbezaan pandangan di antara keduanya dalam menentukan konsep kebahagiaan.

\section{Persamaan}

Aristotle dan Ibnu Miskawayh bersetuju kebahagiaan sebagai matlamat akhir dalam kehidupan manusia. Persamaan yang dapat dilihat adalah dari segi kebahagiaan sebagai matlamat akhir dan kebahagiaan adalah matlamat akhir tindakan dan perlakuan. Sejak awal lagi, Aristotle menyebut kebahagiaan adalah sesuatu yang muktamad dan mandiri, dan kebahagiaan sebagai matlamat akhir tindakan dan perlakuan berdasarkan pandangan beliau (Happiness, then, is something final and self-sufficient, and is the end of action) yang disebut sebagai eudaimonia (Annas 1993). Malah, teori etika Aristotle adalah berdasarkan kerangka tersebut dan amat penting untuk memahaminya sebagai asas keseluruhan teori etikanya yang meletakkan pencarian kebahagiaan sebagai asas perbincangan falsafah etika Yunani klasik. Manakala Ibnu Miskawayh meletakkan kebahagiaan hasil manifestasi dari tingkah laku dan perlakuan.

Aristotle dan Ibnu Miskawayh turut berkongsi pandangan yang sama melalui konsep kebaikan tertinggi. Mereka mengulas mengenai kekeliruan ramai terhadap beberapa kebaikan lain seperti kekayaan, kesihatan dan keseronokan yang dianggap sebagai kebahagiaan. Aristotle dan Ibn Miskawayh bersetuju bahawa kekayaan, kesihatan, keseronokan dan sebagainya bersifat kebaikan tertinggi yang menjadi tujuan utama manusia bukanlah kebahagiaan yang sebenar. Nilai yang selalu dibincangkan iaitu keseronokan lebih mendekati ciri kehaiwanan dan kekayaan hanyalah bersifat material dan boleh menyebabkan kehancuran dari sudut moral terhadap manusia. Selain itu, fokus kekayaan hanyalah untuk mendapatkan harta material seperti wang, rumah dan sebagainya, manakala kesihatan untuk mendapatkan tubuh fizikal yang kuat. Mereka menekankan bahawa kebahagiaan sebagai kebaikan terakhir dan tertinggi serta kebaikan yang penamat serta tidak bersetuju kekayaan dan keseronokan sebagai kebaikan tertinggi seterusnya sebagai tujuan utama dalam kehidupan.

Fungsi akal mendapat tempat dalam perbahasan Aristole dan juga Ibnu Miskawayh. Menurut Aristotle seseorang mencapai tujuan terakhir dengan menjalankan fungsinya dengan 
baik iaitu akalnya. Ibnu Miskawayh turut meletakkan fungsi akal sebagai fungsi yang khusus dan meletakkan kesempurnaan seseorang terletak pada perbuatannya yang berpandukan akal. Menurut mereka, jika akal berfungsi dengan baik, dengan memaksimumkan penggunaannya, maka kebahagiaan tidak akan dapat dicapai. Namun Aristotle lebih memperincikan perbincangan akalnya dengan membahagikan akal kepada dua bahagian iaitu akal digerakkan oleh dua kebaikan iaitu kebaikan intelektual dan kebaikan moral. Kebaikan intelektual dapat menyempurnakan akal, manakala untuk kebaikan moral, akal menjalankan pilihan yang perlu dalam kehidupan seharian.

\section{Perbezaan}

Kerangka kebahagiaan Ibnu Miskawayh lebih bersifat spiritual, sesuai dengan perbahasan beliau dari sudut pandangan seorang muslim. Ini dapat dilihat beliau meletakkan kepentingan jiwa dan hati yang bersih sebagai syarat dan cara memperoleh kebahagiaan. Mereka yang membersihkan jiwanya dari keindahan duniawi sebenarnya mereka telah berjaya untuk menyediakan diri mereka secara spiritual untuk menghadap penciptanya. Justeru, apa yang dapat difahami adalah kebahagiaan bukan sahaja dapat dicapai di dunia, malah pencapaian kebahagiaan di akhirat lebih diutamakan. Berbanding Aristotle yang membincangkan pencapaian kebahagiaan hanya dalam bentuk keduniaan sahaja. Ini boleh dilihat bahawa beliau menekankan kebahagiaan dengan aspek politik. Sebagaimana yang telah disebut, berpolitik bermaksud keterlibatan masyarakat dalam hal-hal bernegara dan menguruskan masyarakat sehingga mewujudkan individu yang mematuhi peraturan dan undang-undang negara. Aktiviti tersebut dapat membawa seseorang ke dalam kebahagiaan.

Konsep pertengahan dibincangkan oleh Aristotle adalah penerus kepada perbincangan fungsi akal. Manakala Ibnu Miskawayh tidak memperincikan fungsi akal hingga terbitnya perbincangan mengenai konsep pertengahan. Di sini Aristotle lebih memperincikan membahaskan fungsi akal hingga segala tingkah laku perbuatan manusia haruslah dipandu dengan jalan tengah. Namun Ibnu Miskawayh lebih menumpukan kepada kesempurnaan sesebuah perbuatan seorang manusia, kesempurnaan seseorang terletak pada perbuatannya yang berpandukan akal, namun yang lebih sempurna adalah aktiviti yang berkait dengan berfikir, menaakul, merenung dan sebagainya.

Ibnu Miskawayh merumuskan cara mendapatkan kebahagiaan dengan dua perkara yang penting iaitu dengan hikmah (pengetahuan) dan penyucian jiwa. Berbeza dengan Aristotle, manusia dapat menjalankan fungsinya dengan baik, dengan cara seseorang itu telah mencapai sesuatu tujuan dan menjustifikasikan konsep pertengahan dalam kehidupan, menggunakan sepenuhnya keupayaan akal secara maksimum serta menunjukkan kecemerlangan dalam tingkah lakunya, dengan menggabungkan keseluruhan aspek tersebut, maka seseorang itu sudah mencapai kebahagiaan. Secara sepintas lalu, perbahasan Aristotle wujud sedikit kepentingan hikmah seperti aktiviti berfikir, namun elemen penyucian jiwa tidak wujud dalam perbahasannya. Penyucian jiwa adalah persediaan seseorang untuk bertemu Tuhannya selepas kematian menurut Ibnu Miskawayh berbanding Aristotle yang tidak menyatakan penyucian jiwa kerana masyarakat Yunani klasik tidak mempercayai ada kehidupan selepas kematian.

\section{KESIMPULAN}

Konsep kebahagiaan telah dibincangkan sejak dahulu dan dikemaskinikan oleh Aristole secara sistematik. Perbincangan kebahagiaan diteruskan secara teratur pada masa Ibnu Miskawayh walaupun telah dibincangkan oleh Aristotle. Walaupun perbincangan Ibnu Miskawayh 
kelihatan hampir sama dengan idea Aristotle seperti keseronokan tiada tempat bagi mencapai kebahagiaan, namun wacana kebahagiaan Ibnu Miskawayh lebih bersandarkan kepada asas akhlak Islam. Dari satu sudut, Ibn Miskawayh cuba mengharmonikan nilai-nilai Islam dengan logik falsafah. Konsep eudaimonia Aristotle dan kebahagiaan Ibn Miskwayh kelihatan selari dengan ajaran Islam, seperti memberi perhatian terhadap fungsi nalaran serta memahami kebaikan dan kesederhanaan. Ini menunjukkan perbincangan ini sangat penting bagi memberikan petanda aras dalam falsafah etika. Dari kebahagiaanlah lahirnya perbincangan falsafah etika, tidak kira aliran pemikiran, agama atau bangsa yang berfalsafah. Apa yang kurang dalam perbincangan kebahagiaan ahli falsafah Yunani seperti Aristotle ialah hubungan kebahagiaan dengan aspek ketuhanan. Ahli falsafah akhlak Islam seperti Ibn Miskawayh telah pun mengaitkan kebahagiaan dengan lebih komprehensif dan dipenuhi dengan nilai keislaman iaitu memasukkan unsur ketuhanan.

\section{RUJUKAN}

Açikgenç, A. 2008. Aristotelian and Islamic Moral Philosophy A Comparative Ethics. alShajarah 13: 125-146.

Anagnostopoulos, G. 2009. The Blackwell Companion to Aristotle. Oxford: Blackwell Publishing.

Annas, J. 1998. Virtue and Eudaimonism. Social Philosophy and Policy 15(1): 37-55.

Annas, J. 1993. The Morality of Happiness. Oxford: Oxford University Press.

Annas S. A. 2019. Pemikiran kebahagiaan dalam tamadun Yunani klasik 470 S.M-529 M.: Satu Analisis Ringkas. Jurnal Peradaban 12 (1): 1-25.

Ansari, A. H. 1963. Miskawayh's Conception of Sa'adah. Islamic Studies 2(3): 317-335.

Aristotle. 1962. Nicomachean Ethics. Trans. Martin Oswold. Indianapolis: Bobbs Marill.

Bertans, K. 2003. Etika dan Moral untuk Pengajian Tinggi, Kuala Lumpur: Penerbit Universiti Malaya.

Cooper, J. M. 1986. Reason and Human Good in Aristotle. Indianapolis: Hackett Publishing.

Cunningham, S. B. 1999. Getting it Right: Aristotle's Golden Mean as Theory Deterioration. Journal of Mass Media Ethics 14(1): 5-15.

Godfrey, F. L. T. 1953. The Idea of The Mean. Hermathena 81: 14-28.

Horten, M. 1974. Moral Philosophers in Islam. Islamic Studies, 13(1): 1-23.

Ibnu Miskawayh. 1968. The refinement of character. A translation from the Arabic of Ahmad Ibnu-Muhammad Miskawayh's Tahdhib al-Akhlaq by Constantine K. Zurayk. Beirut: American University of Beirut.

Ibnu Miskawayh. 1977. Tahdhib al-Akhlaq wa Tathir al-A'raq. Beirut: Dar Maktabah alHayat.

Idris Zakaria \& Ahmad Sunawari Long. 2013. Titik Temu Antara Falsafah dan Kehidupan Praktis. International Journal of Islamic Thought 3: 37-44.

Kraut, R. 1979. Two Conception of Happiness. The Philosophical Review 88(2): 167-197.

Lim, M. H. S. 1996. Eudaimonia: The Argument of the Ethics. Master Thesis, Universiti Kebangsaan Singapura.

Majid Fakhry. 1994. Ethical theories in Islam. Leiden: E.J. Brill.

Muhammad Abdul. Quasem. 1975. Al-Ghazali Conception of Happiness. Arabica 22: 153161.

Nasir Omar. 2003. Christian and Muslim Ethicsh: a Study How To Attain Happiness as Reflected in the Works on Thahdhib al-Akhlaq by Yahya Ibnu 'Adi (d.974) and Miskawayh (d.1030). Kuala Lumpur: Dewan Bahasa dan Pustaka.

Nasir Omar. 2010. Falsafah Akhlak, Bangi: Penerbit Universiti Kebangsaan Malaysia. 
Othman Lebar. 2012. Penyelidikan Kualitatif Pengenalan kepada Teori dan Metode. Tanjong Malim: Penerbit Universiti Pendidikan Sultan Idris.

O'Grady, Patricia F. 2005. Meet the Philosophers of Ancient Greece. England: Ashgate Publishing Limited.

Prior, W. J. 2001. Eudaimonism and Virtue. The Journal of Value Inquiry 35: 325-342.

Smith, N. D. 2001. Some Thoughts about the Origin of Greek Ethics. The Journal of Ethics 5(1): 3-20.

Stumpf, S. E.1994. Philosophy: History and Problems. New York: McGraw Hill.

Urmson, J. O. 1973. Aristotle's Doctrine of the Mean. American Philosophical Quarterly 10(13): 223-230.

\section{MOHD ANNAS SHAFIQ BIN AYOB}

Pusat Asasi UiTM Kampus Dengkil

Akademi Pengajian Islam Kontemporari

Universiti Teknologi Mara

43800 Dengkil, Selangor, Malaysia

MOHD NORAZRI MOHAMAD ZAINI

Akademi Pengajian Islam Kontemporari

Universiti Teknologi Mara

40450 Shah Alam, Selangor, Malaysia

E-mel: norazri7082@uitm.edu.my

FARIDAH MOHD SAIRI

Pusat Asasi UiTM Kampus Dengkil

Akademi Pengajian Islam Kontemporari

Universiti Teknologi Mara

43800 Dengkil, Selangor, Malaysia

E-mel: faridah0052@uitm.edu.my

NOOR SYAHIDA MD SOH

Pusat Asasi UiTM Kampus Dengkil

Akademi Pengajian Islam Kontemporari

Universiti Teknologi Mara

43800 Dengkil, Selangor, Malaysia

E-mel: noors8233@uitm.edu.my

*Pengarang untuk surat menyurat: mohdannas0382@uitm.edu.my 